\title{
Hyppig, fryktet og mangfoldig
}

Medfødt cytomegalovirusinfeksjon (CMV) er en fryktet tilstand fordi den kan fremtre med et vidt spektrum av kliniske manifestasjoner - fra de milde til de alvorligste. Det er nyttig at Calisch og medarbeidere belyser problemstillingen med en kasuistikk. Denne den hyppigste medfødte infeksjon hos mennesker har en insidens på $0,2-2,5 \%$ (1). Den største risikofaktor for smitte for en gravid kvinne er nærkontakt med barn under to år (2).

I motsetning til smitte med de fleste andre herpesvirus er fostrene som er smittet av dette DNA-viruset symptomfrie eller har få kliniske symptomer ved fødselen. Hele $90 \%$ av de smittede barna er asymptomatiske ved fødselen, men $10-20 \%$ av disse utvikler senere sekveler i form av hørselstap, korioretinitt eller forsinket utvikling. De viktigste kliniske tegn er gulsott, petekkier og hepatosplenomegali (1). Alle disse ble funnet hos barnet som er beskrevet av Calisch og medarbeidere. Andre symptomer og tegn er oligo- og polyhydramnion, prematuritet, intrauterin veksthemming, hypotoni, dårlig vektøkning, forstørrede hjerneventrikler, mikrokefali og intrakraniale og periventrikulære forkalkninger $(1,2)$. I den senere tid er man blitt klar over at cytomegalovirusinfeksjoner påvirker nevronmigrasjonen fra ventriklene til cortex som skjer i fosterlivet. Dette kan føre til polymikrogyri, lissenkefali og skade av hvit substans (3).

Som nevnt av Calisch og medarbeidere er differensialdiagnosene først og fremst andre infeksjoner, som toksoplasmose, rubella, herpes simplex og syfilis. Sepsis, erytroblastose og metabolske tilstander som galakto- semi og tyrosinemi er også differensialdiagnoser. I en studie med spedbarn under seks måneder med trombocytopeni som eneste kliniske manifestasjon, var nesten $30 \%$ positive for cytomegalovirus (4). Trombocytopeni ved cytomegalovirusinfeksjon er for øvrig et dårlig prognostisk tegn, og trombocytopeni alene bør lede tanken mot cytomegalovirusinfeksjon eller andre medfødte infeksjoner. Det er ikke alltid trombcytopenien ledsages av petekkier (4).

Er det riktig å avslutte aktiv behandling hos et barn, som beskrevet av Calisch og medarbeidere? Nå skriver de ikke noe om hvilken behandling de ga og dermed seponerte. Men hvis de med å «avslutte all videre behandling ved to døgns alder» mener intensivbehandling, f.eks. respiratorbehandling, så kan jeg i dette tilfellet slutte meg til det. Uttrykket «all videre behandling» kan imidlertid virke uheldig, da det ikke går frem at man i en terminalfase fortsatt skal gi pleie og palliativ behandling, noe som ofte er like krevende som intensivbehandling.

I dag screenes det ikke rutinemessig for cytomegalovirusinfeksjon. Det er fordi den totale risikoen for symptomatisk infeksjon er så lav som $0,2 \%$ og fordi det ikke finnes gode behandlingsalternativer. Langvarig antiviral behandling av barn med symptomatisk medfødt cytomegalovirusinfeksjon ser ut til å gi mindre skade på syn og hørsel. Det viktigste er imidlertid å redusere primærinfeksjoner hos gravide. Det kan man gjøre ved å screene blodprodukter til gravide med tanke på cytomegalovirus. Intervensjon i form av smittebeskyttelse før svangerskapet har ikke vært vellykket, mens det i svan- gerskapet synes å være mer effektivt. Hvis kvinnen har små barn, kan risikoen for overføring reduseres med hygieniske tiltak som håndvask (2). CMV-hyperimmunglobulin gitt til gravide med primær cytomegalovirusinfeksjon ser ut til å beskytte (2). I fremtiden vil behandling med CMVhyperimmunglobulin av både kvinnen og det nyfødte barnet kunne bli en del av standarden. En mer systematisk cytomegalovirusscreening av den gravide kvinne i første trimester vil kunne tvinge seg frem, og kanskje vil det kunne utvikles en vaksine $(1,2)$.

\section{Ola Didrik Saugstad}

odsaugstad@rr-research.no

Pediatrisk forskningsinstitutt

Oslo universitetssykehus, Rikshospitalet

Postboks 4950 Nydalen

0424 Oslo

Oppgitte interessekonflikter: Ingen

\section{Litteratur}

1. Syggelou S, Lacovideou N, Kloudas S et al. Congenital cytomegalovirus infection. Ann NY Acad Sci 2010: 1205: $144-7$

2. Adler SP, Nigro G, Pereira L. Recent advances in the prevention and treatment of congenital cytomegalovirus infections. Semin Perinatol 2007; 31 $10-8$.

3. Tsutsui Y. Effects of cytomegalovirus infection on embryogenesis and brain development. Congenit Anom (Kyoto) 2009; 49: 47-55.

4. Kang JW, Kim GN, Kim SY et al. Clinical and radiological evaluation of cytomegalovirus-induced thrombocytopenia in infants between 1 and 6 months of age. Korean J Hematol 2010; 45: 29-35.

Mottatt 21.12. 2010, første revisjon innsendt 5.1. 2011, godkjent 6.1. 2011. Medisinsk redaktør Siri Lunde. 